\title{
Transmission Model of HIV with and without Antiretroviral Drugs
}

\author{
P.Pongsumpun
}

\begin{abstract}
AIDS or Acquired Immune Deficiency Syndrome (AIDS) is caused by a virus infection.Human Immunodeficiency Virus also known as HIV. HIV infection destroys white blood cells that are immune to infection, causing the infected patient to become immunocompromised. Infectious diseases such as tuberculosis, pneumonia, infection in the blood system, fungus, etc. HIV infection destroys white blood cells that are immune to infection, causing the infected patient to become immunocompromised. In this study, we formulate the transmission model for describing the occurrence of HIV patients with and without antiretroviral drugs. The standard dynamical modeling method is used for analyzing our model in this study.
\end{abstract}

Index Terms - HIV, model, standard dynamic modeling method, transmission.

\section{INTRODUCTION}

Acquired immune deficiency syndrome (AIDS) is a spectrum of conditions caused by infection with the human immunodeficiency virus (HIV) [1]. During the initial infection, each person may not have any symptom or may have a brief period of influenza-like illness [2]. AIDS is a disease caused by the HIV virus. The virus will result in a drop in the level of white blood cells called CD4. Patients develop the symptoms of HIV slowly. The symptoms will appear when the CD4 level is less than 200 cells per square millimeter. The average rate of infection in Thailand is 7-10 years. HIV is in the body but not sick because it is still controlled by immunity. The transmission of HIV can happen via the sexual transmission, perinatal transmission and blood transmission. Sexual transmission can happen when there is the contact with infected sexual fluids. An infectious mother with HIV can transmit HIV to her children during childbirth, pregnancy, and also through breastfeeding. The transmission of HIV through blood transfusion also be occurred. The symptoms of HIV patients are fever, chills, joint pain, muscle aches, sore throat, enlarged glands, a red rash, tiredness, weakness, unintentional weight loss and thrush. Some HIV patients have no symptoms until several months or years after infected with the virus. About 80 percent of people can develop symptoms similar to flu 2-6 weeks after infecting with the virus[3]. Many species of mammals are infected by lentiviruses. The incubation period for this virus has a long time[4]. It can be transmitted as single-stranded, positive-sense, enveloped RNA viruses.

When it entry into the target cell, the viral RNA genome is

P.Pongsumpun is with Department of Mathematics, Faculty of Science, King Mongkut's Institute of Technology Ladkrabang,Chalongkrung road, Ladkrabang, Bangkok 10520, converted into double-stranded DNA by a virally encoded reverse transcriptase. The resulting viral DNA is then imported into the cell nucleus and integrated into the cellular DNA by a virally encoded integrase and host co-factors[5].

An illness of HIV patients are caused by the destroy of the immune system. The pathogen can easily move to the body. When the immune system is destroyed, the symptoms can appear.

There is a chronic lower respiratory tract infection, for example: severe lymphadenopathy or enlarged spleen with fungal infection, white skin in the mouth and cough, chronic skin rash, weight reduction, etc.The amount of HIV received. If the person get AIDS, the chance of getting AIDS is higher. If there is a wound, it will make it easier for AIDS to enter the wound and become infected with AIDS. If the number of contacts with HIV patients is higher, then the higher chance of getting HIV. Other infections such as ulceration, chills, herpes, resulting in white blood cells in many lesions, it is easy to get AIDS. And it is a way to get AIDS into the wound faster.

Health of the recipient, if the health of the body is not healthy at the moment, then it is likely to get infected easier. The first anti-HIV drug was invented in 1987 and in the following years. Many scientists have tried to develop anti-viral drugs, HIV or drugs that will stop the growth of HIV in more than 30 species such as Zidovudine (ZDV), also known as azidothymidine (AZT), is an antiretroviral medication used to prevent and treat HIV/AIDS[6]. It is recommended for use with other antiretrovirals. It was first discovered in 1964 and approved in the United States in 1986[7]. Truvada is an antiretroviral drug that consists of two drugs, Tenofovir and Emtricitabine. Both drugs support the treatment of AIDS each other.Mathematical model were applied to describe the transmission of HIV/AIDS. In 2009, Naresh,Tripathi and Sharma [8] formulated and analyzed mathematical model for the transmission of HIV with the different total human populations. The movement of HIV patients was considered. In 2014,BozkurtandPeker[9] formulated the mathematical model by separating the human population into 3 classes such as HIV negative class, HIV positive class and asymptomatic class. In this study, we use the transmission model for describing the transmission model of HIV/AIDS with and without antiretroviral drugs.

\section{TRANSMISSION MODEL}

Our model consists of 3 population classes such as susceptible human, infectious human with antiretroviral drugs and infectious human without antiretroviral drugs. The diagram of our model is described as follows: 


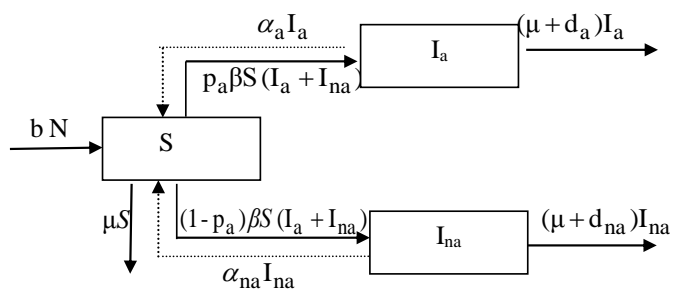

Fig 1. Diagram of our model

From figure1, we can write the system of equations as follows:

$\frac{\mathrm{d}}{\mathrm{dt}} \mathrm{S}=\mathrm{bN}+\alpha_{\mathrm{a}} \mathrm{I}_{\mathrm{a}}+\alpha_{\mathrm{na}} \mathrm{I}_{\mathrm{na}}-\beta S\left(\mathrm{I}_{\mathrm{a}}+\mathrm{I}_{\mathrm{na}}\right)-\mu S$

$\frac{\mathrm{d}}{\mathrm{dt}} \mathrm{I}_{\mathrm{a}}=-\alpha_{\mathrm{a}} \mathrm{I}_{\mathrm{a}}+\mathrm{p}_{\mathrm{a}} \beta \mathrm{S}\left(\mathrm{I}_{\mathrm{a}}+\mathrm{I}_{\mathrm{na}}\right)-\left(\mu+\mathrm{d}_{\mathrm{a}}\right) \mathrm{I}_{\mathrm{a}}$

$\frac{\mathrm{d}}{\mathrm{dt}} \mathrm{I}_{\mathrm{na}}=\left(1-\mathrm{p}_{\mathrm{a}}\right) \beta S\left(\mathrm{I}_{\mathrm{a}}+\mathrm{I}_{\mathrm{na}}\right)-\alpha_{\mathrm{na}} \mathrm{I}_{\mathrm{na}}-\left(\mu+\mathrm{d}_{\mathrm{na}}\right) \mathrm{I}_{\mathrm{na}}$

with $\mathrm{S}+\mathrm{I}_{\mathrm{a}}+\mathrm{I}_{\mathrm{na}}=\mathrm{N}$.

The variables and parameters of our model are denoted in table 1.

TABLE I. THE VARIABLES AND PARAMETERS OF OUR MODEL

\begin{tabular}{|c|c|}
\hline Variables/Parameter & Definition \\
\hline $\mathrm{S}$ & Number of susceptible human population \\
\hline $\mathrm{I}_{\mathrm{a}}$ & $\begin{array}{l}\text { Number of infectious human population } \\
\text { with antiretroviral drugs }\end{array}$ \\
\hline $\mathrm{I}_{\text {na }}$ & $\begin{array}{l}\text { Number of infectious human population } \\
\text { without antiretroviral drugs }\end{array}$ \\
\hline$\beta$ & HIV infection rate \\
\hline $\mathrm{b}$ & Birth rate of human population \\
\hline $\mathrm{N}$ & Total population \\
\hline$\alpha_{\mathrm{a}}$ & $\begin{array}{l}\text { Rate at which the infectious human } \\
\text { population withantiretroviral drugs become to } \\
\text { be susceptible. }\end{array}$ \\
\hline$\alpha_{\text {na }}$ & $\begin{array}{l}\text { Rate at which the infectious human } \\
\text { population without antiretroviral drugs } \\
\text { become to be susceptible. }\end{array}$ \\
\hline $\mathrm{p}_{\mathrm{a}}$ & $\begin{array}{l}\text { Probability of HIV patients who get } \\
\text { antiretroviral drugs }\end{array}$ \\
\hline$\beta$ & HIV contact rate \\
\hline$\mu$ & The natural death rate of human population \\
\hline $\mathrm{d}_{\mathrm{a}}$ & $\begin{array}{l}\text { The death rate of HIV patients with } \\
\text { antiretroviral drugs }\end{array}$ \\
\hline $\mathrm{d}_{\text {na }}$ & $\begin{array}{l}\text { The death rate of HIV patients without } \\
\text { antiretroviral drugs }\end{array}$ \\
\hline
\end{tabular}

We normalize our equations(1)-(3) by letting

$$
\mathrm{s}=\mathrm{S} / \mathrm{N}, \mathrm{i}_{\mathrm{a}}=\mathrm{I}_{\mathrm{a}} / \mathrm{N}, \mathrm{i}_{\mathrm{na}}=\mathrm{I}_{\mathrm{na}} / \mathrm{N},
$$

then the reduced equations become

$$
\begin{gathered}
\frac{\mathrm{d}}{\mathrm{dt}} \mathrm{s}=\mathrm{b}+\alpha_{\mathrm{a}} \mathrm{i}_{\mathrm{a}}+\alpha_{\text {na }} \mathrm{i}_{\mathrm{na}}-\left(\mu+\beta\left(\mathrm{i}_{\mathrm{a}}+\mathrm{i}_{\text {na }}\right) \mathrm{N}\right) \mathrm{s} \\
\frac{\mathrm{d}}{\mathrm{dt}} \mathrm{i}_{\mathrm{a}}=-\mathrm{i}_{\mathrm{a}}\left(\alpha_{\mathrm{a}}+\mathrm{d}_{\mathrm{a}}+\mu\right)+\beta\left(\mathrm{i}_{\mathrm{a}}+\mathrm{i}_{\text {na }}\right) N \mathrm{p}_{\mathrm{a}} \mathrm{s}
\end{gathered}
$$

$\frac{\mathrm{d}}{\mathrm{dt}} \mathrm{i}_{\text {na }}=-\mathrm{i}_{\text {na }}\left(\alpha_{\text {na }}+\mathrm{d}_{\text {na }}+\mu\right)+\beta\left(\mathrm{i}_{\mathrm{a}}+\mathrm{i}_{\text {na }}\right) \mathrm{N}\left(1-\mathrm{p}_{\mathrm{a}}\right) \mathrm{s}$

with $\mathrm{s}+\mathrm{i}_{\mathrm{a}}+\mathrm{i}_{\text {na }}=1$.

\section{A. Analytical Results}

By using standard dynamical modeling method[10], the steady states can be found by setting the right hand side of (4)-(6) to zero. The steady states are

$$
\text { i) Disease free state }: \mathrm{E}_{0}=\left(\frac{\mathrm{b}}{\mu}, 0,0\right)
$$

ii) Endemic steady state $: \mathrm{E}_{1}=\left(\mathrm{s}^{*}, \mathrm{i}_{\mathrm{a}}^{*}, \mathrm{i}_{\text {na }}^{*}\right)$ where

$$
\begin{aligned}
& \mathrm{s}^{*}=\frac{\left(\alpha_{\mathrm{a}}+\mathrm{d}_{\mathrm{a}}+\mu\right)\left(\alpha_{\mathrm{na}}+\mathrm{d}_{\mathrm{na}}+\mu\right)}{\beta\left(\alpha_{\mathrm{a}}+\mathrm{d}_{\mathrm{a}}+\mu\right) \mathrm{N}+\beta\left(\alpha_{\mathrm{na}}-\alpha_{\mathrm{a}}+\mathrm{d}_{\mathrm{na}}-\mathrm{d}_{\mathrm{a}}\right)}, \\
& \left.\left.\mathrm{i}_{\mathrm{a}}^{*}=\frac{\left(\alpha_{\mathrm{na}}+\mathrm{d}_{\mathrm{a}}+\mu\right) \mathrm{p}_{\mathrm{a}}\left(\left(\alpha_{\mathrm{a}}+\mathrm{d}_{\mathrm{a}}+\mu\right)\left(\mathrm{b} \beta \mathrm{N}-\mu\left(\alpha_{\mathrm{na}}+\mathrm{d}_{\mathrm{na}}+\mu\right)\right)\right.}{\beta \mathrm{N}\left(\alpha_{\mathrm{a}+} \mathrm{d}_{\mathrm{a}}+\mu+\left(\mathrm{d}_{\mathrm{a}}\right) \mathrm{b} \beta \mathrm{Np}_{\mathrm{a}}\right)}-\alpha_{\mathrm{a}}+\mathrm{d}_{\mathrm{na}}-\mathrm{d}_{\mathrm{a}}\right) \mathrm{p}_{\mathrm{a}}\right) \\
& \left(\alpha_{\mathrm{a}}\left(\mathrm{d}_{\mathrm{na}}+\mu\right)\left(1-\mathrm{p}_{\mathrm{a}}\right)+\left(d_{\mathrm{a}}+\mu\right)\left(\mathrm{d}_{\mathrm{na}}+\mu+\alpha_{\mathrm{na}} \mathrm{p}_{\mathrm{a}}\right)\right)
\end{aligned}
$$

$$
\begin{gathered}
\left(\alpha_{\mathrm{na}}+\mathrm{d}_{\mathrm{a}}+\mu\right)\left(-1+\mathrm{p}_{\mathrm{a}}\right)\left(\left(\alpha_{\mathrm{a}}+\mathrm{d}_{\mathrm{a}}+\mu\right)(\mathrm{b} \beta \mathrm{N}\right. \\
\mathrm{i}_{\mathrm{na}}^{*}=\frac{\left.\left.-\mu\left(\alpha_{\mathrm{na}}+\mathrm{d}_{\mathrm{na}}+\mu\right)\right)+\left(\alpha_{\mathrm{na}}-\alpha_{\mathrm{a}}+\mathrm{d}_{\mathrm{na}}-\mathrm{d}_{\mathrm{a}}\right) \mathrm{b} \beta \mathrm{Np}_{\mathrm{a}}\right)}{\beta \mathrm{N}\left(\alpha_{\mathrm{a}+} \mathrm{d}_{\mathrm{a}}+\mu+\left(\alpha_{\mathrm{na}}-\alpha_{\mathrm{a}}+\mathrm{d}_{\mathrm{na}}-\mathrm{d}_{\mathrm{a}}\right) \mathrm{p}_{\mathrm{a}}\right)} \\
\left(\alpha_{\mathrm{a}}\left(\mathrm{d}_{\mathrm{na}}+\mu\right)\left(-1+\mathrm{p}_{\mathrm{a}}\right)-\left(d_{\mathrm{a}}+\mu\right)\left(\mathrm{d}_{\mathrm{na}}+\mu+\alpha_{\mathrm{na}} \mathrm{p}_{\mathrm{a}}\right)\right)
\end{gathered}
$$

Local stability of each steady state can be determined by checking the sign of real part of all eigenvalues. If all eigenvalues have negative real parts then that steady state will be local stable.

Eigenvalues for each steady state can be found from solving

$$
\operatorname{det}(\mathrm{J}-\lambda \mathrm{I})=0
$$

where is the Jacobian matrix evaluated at each steady state and $\mathrm{I}$ is the identity matrix.

i) Disease free state : 
The Jacobian matrix is given by

$$
\mathrm{J}_{\mathrm{E}_{0}}=\left(\begin{array}{ccc}
-\mu & \alpha_{\mathrm{a}}-(b / \mu) \beta \mathrm{N} & \alpha_{\mathrm{na}}-(b / \mu) \beta \mathrm{N} \\
0 & -\alpha_{\mathrm{a}}-\left(d_{a}+\mu\right) & (b / \mu) \beta \mathrm{Np}_{\mathrm{a}} \\
& +(b / \mu) \beta \mathrm{Np}_{\mathrm{a}} & -\alpha_{\mathrm{na}}-\left(d_{a}+\mu\right) \\
0 & (b / \mu) \beta \mathrm{N}\left(1-\mathrm{p}_{\mathrm{a}}\right) & +(b / \mu) \beta \mathrm{N}\left(1-\mathrm{p}_{\mathrm{a}}\right)
\end{array}\right) .
$$

The eigenvalues are the solutions from solving

$$
\operatorname{Det}\left(\begin{array}{ccc}
-\mu-\lambda & \alpha_{\mathrm{a}}-(b / \mu) \beta \mathrm{N} & \alpha_{\mathrm{na}}-(b / \mu) \beta \mathrm{N} \\
0 & -\alpha_{\mathrm{a}}-\left(d_{a}+\mu\right) & (b / \mu) \beta \mathrm{Np}_{\mathrm{a}} \\
+(b / \mu) \beta \mathrm{Np}_{\mathrm{a}}-\lambda & -\alpha_{\mathrm{na}}-\left(d_{a}+\mu\right) \\
0 & (b / \mu) \beta \mathrm{N}\left(1-\mathrm{p}_{\mathrm{a}}\right) & +(b / \mu) \beta \mathrm{N}\left(1-\mathrm{p}_{\mathrm{a}}\right)-\lambda
\end{array}\right)=0 .
$$

Thus, the eigenvalues are

$$
\begin{aligned}
& \lambda_{1}=-\mu, \lambda_{2,3}=\frac{1}{2 \mu}\left(-\mu\left(\alpha_{\mathrm{a}}+\mathrm{d}_{\mathrm{a}}+\mu+\alpha_{\mathrm{na}}+\mathrm{d}_{\mathrm{na}}+\mu\right)\right) \\
& +b \beta N \\
& \pm \sqrt{\left.\begin{array}{l}
\left(\mu\left(\alpha_{\mathrm{a}}-\alpha_{\mathrm{na}}+\mathrm{d}_{\mathrm{a}}-\mathrm{d}_{\mathrm{na}}\right)+b \beta \mathrm{N}\right)^{2} \\
-4\left(\alpha_{\mathrm{a}}-\alpha_{\mathrm{na}}+\mathrm{d}_{\mathrm{na}}-\mathrm{d}_{\mathrm{a}}\right) b \beta \mu \mathrm{Np}_{\mathrm{a}}
\end{array}\right) .}
\end{aligned}
$$

All above eigenvalues have negative real parts for $\mathrm{L}<1$, where

$$
\mathrm{L}=\frac{\mathrm{b} \beta \mathrm{N}}{\mu\left(\alpha_{\mathrm{a}}+d_{a}+\mu+\alpha_{\mathrm{na}}+d_{n a}+\mu\right)} .
$$

Therefore the disease free state is local stable for $\mathrm{L}<1$.

ii) Endemic disease state:

The Jacobian matrix is given by

$$
\mathrm{J}_{\mathrm{E}_{1}}=\left(\begin{array}{ccc}
-\mu-\beta \mathrm{N}\left(\mathrm{i}_{\mathrm{a}}^{*}+\mathrm{i}_{\mathrm{na}}^{*}\right) & \alpha_{\mathrm{a}}-\beta \mathrm{Ns}{ }^{*} & \alpha_{\mathrm{na}}-\beta \mathrm{Ns}^{*} \\
\beta \mathrm{N}\left(\mathrm{i}_{\mathrm{a}}^{*}+\mathrm{i}_{\mathrm{na}}^{*}\right) \mathrm{p}_{\mathrm{a}} & -\alpha_{\mathrm{a}}-\left(d_{a}+\mu\right) & \beta \mathrm{Np}_{\mathrm{a}} \mathrm{s}^{*} \\
\beta \mathrm{N}\left(\mathrm{i}_{\mathrm{a}}^{*}+\mathrm{Np}_{\mathrm{a}} \mathrm{s}^{*}\right)\left(1-\mathrm{p}_{\mathrm{a}}\right) & \beta \mathrm{N}\left(1-\mathrm{p}_{\mathrm{a}}\right) \mathrm{s}^{*} & -\alpha_{\mathrm{na}}-\left(d_{a}+\mu\right) \\
+\beta \mathrm{N}\left(1-\mathrm{p}_{\mathrm{a}}\right) \mathrm{s}^{*}
\end{array}\right)
$$

where $s^{*}, i_{\mathrm{a}}^{*}$ and $i_{\text {na }}^{*}$ are defined in (8)-(10).

Using the same manner as above, thus the endemic disease state is local stable for $\mathrm{L}>1$.

\section{B. Numerical Results}

\section{For $\mathbf{L}<1$.}

We simulate our equations by using numerical method. The parameters used in this study are $b=1 /(70 * 365)$ corresponds to the 70 years life cycle for human, $\mathrm{N}=$ $1000, \alpha_{\mathrm{a}}=1 /(365 * 10)$ corresponds to the 10 years of HIV infectious human with antiretroviral drugs who can become susceptible again, $\alpha_{\mathrm{na}}=1 / 365$ corresponds to the 1 year of HIV infectious human without antiretroviral drugs who can become susceptible again $\mathrm{p}_{\mathrm{a}}=0.5, \beta=0.000004$ (by assumption) $\mu=1 /(70 * 365)$ corresponds to the 70 years life cycle for human, $\mathrm{d}_{\mathrm{a}}=1 /(365 * 10)$ corresponds to the 10 years of HIV infectious human with antiretroviral drugs who become die. , $\mathrm{d}_{\text {na }}=1 /(365)$. corresponds to the 1 year of HIV infectious human without antiretroviral drugs who become die and $\mathrm{L}=0.0655$.
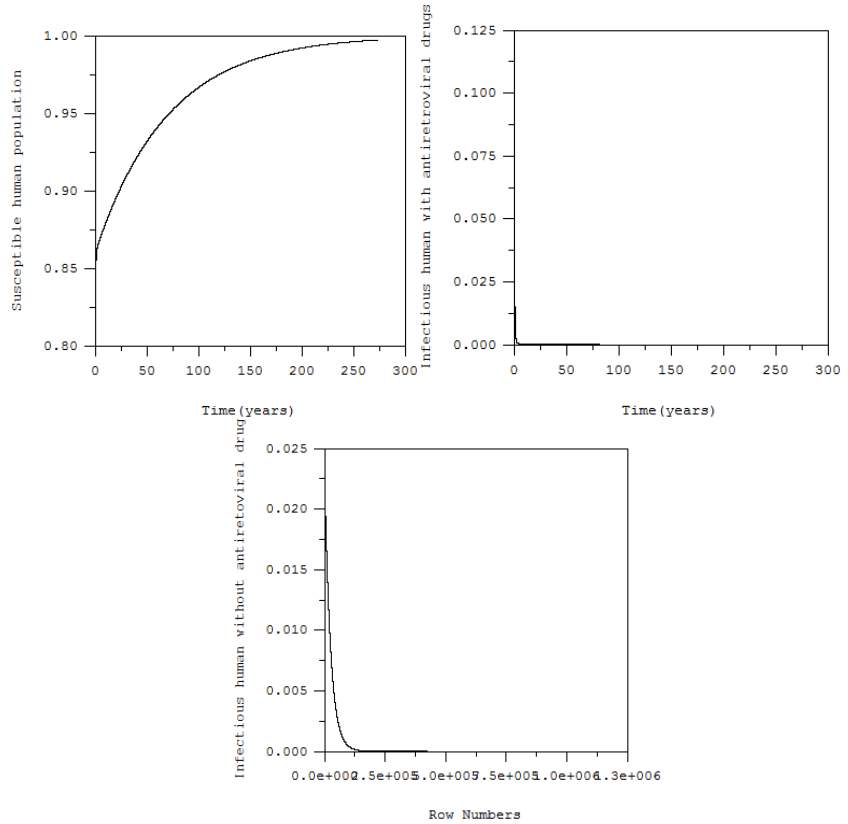

Fig 2. Time series of our model for $\mathrm{L}<1$.

We can see that our results converge to disease free state for $\mathrm{L}<1$.

\section{For $\mathbf{L}>1$.}

We simulate our equations by using numerical method. The parameters used in this study are $b=1 /(70 * 365)$ corresponds to the 70 years life cycle for human, $\mathrm{N}=$ $1000, \alpha_{\mathrm{a}}=1 /(365 * 10)$ corresponds to the 10 years of HIV infectious human with antiretroviral drugs who can become susceptible again, $\alpha_{\text {na }}=1 / 365$ corresponds to the 1 year of HIV infectious human without antiretroviral drugs who can become susceptible again $\mathrm{p}_{\mathrm{a}}=0.5 \quad \beta=0.00004$ (by assumption)corresponds to the 70 years life cycle for human, $\mathrm{d}_{\mathrm{a}}=1 /(365 * 10)$ corresponds to the 10 years of HIV infectious human with antiretroviral drugs who become die. , $\mathrm{d}_{\mathrm{na}}=1 /(365)$. corresponds to the 1 year of HIV infectious human without antiretroviral drugs who become die and $\mathrm{L}=6.55$. 

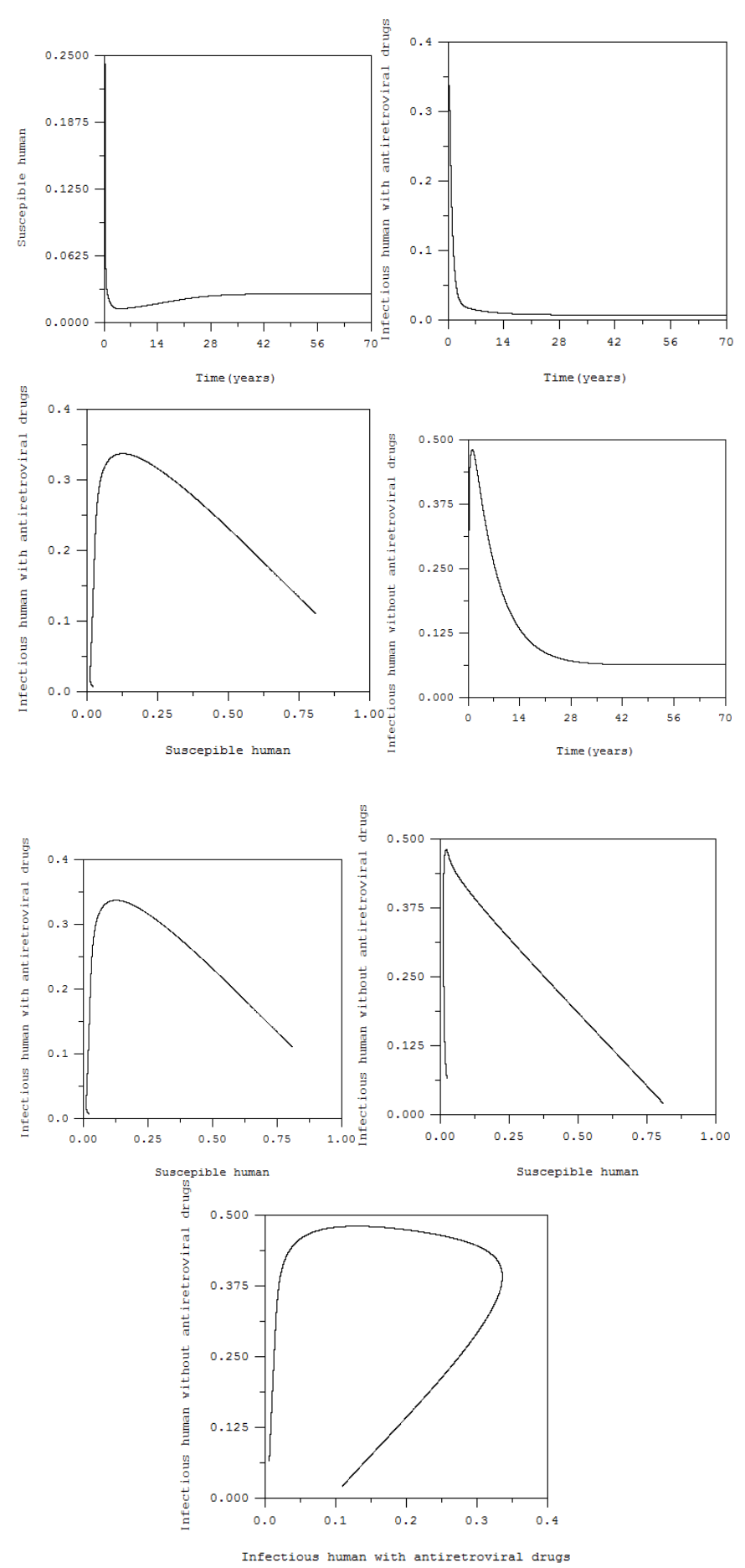

Fig 3. Numerical results of our model for $L>1$.

We can see that our results converge to the endemic equilibrium points for $\mathrm{L}>1$.

\section{CONCLUSION}

In this paper, we describe the transmission of HIV/AIDS by mathematical modeling. The receiving of antiretroviral drugsand without antiretroviral drug are considered.

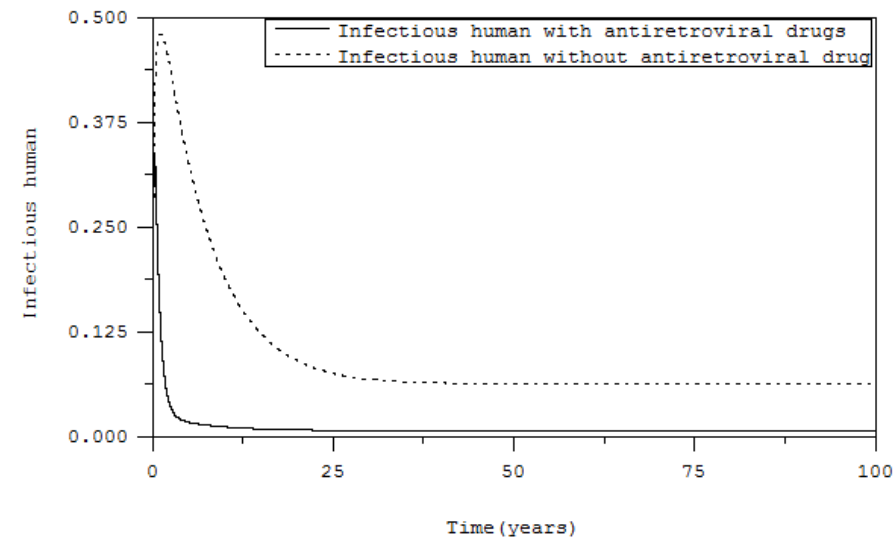

Fig 4. The comparison of the time series solutions of infectious human with antiretroviral drugs and without antitretroviral drug

As shown in figure 4 , we can see that number of infectious human population with antiretroviral drugs converge to the equilibrium state faster than the number of infectious human population withoutantiretroviral drugs. Thus, we can conclude that the antiretroviral drugs influence to the transmission of HIV/AIDS.

\section{ACKNOWLEDGMENT}

This work is supported by Faculty of Science, King Mongkut's Institute of Technology, Thailand. The author would like to thanks KanthichaPhunkaseam, ChidchanokSukkasem and LalitaJuiphan.

\section{REFERENCES}

[1] HIV/AIDS, Available from https://en.wikipedia.org/wiki/HIV/AIDS.

[2] HIV/AIDS Fact sheet $\mathrm{N}^{\circ} 360$, WHO. November 2015.

[3] Explaining HIV and AIDS,Available: https://www.medicalnewstoday.com/articles/17131.php.]

[4] Levy JA (November 1993). "HIV pathogenesis and long-term survival".Aids. $\quad 7 \quad$ (11): doi:10.1097/00002030-199311000-00001. PMID 8280406.]. https://doi.org/10.1097/00002030-199311000-00001

[5] JA.Smith, R.Daniel, 2006, Following the path of the virus: the exploitation of host DNA repair mechanisms by retroviruses, ACS Chemical Biology, 1 (4), 217-26. doi:10.1021/cb600131q. PMID 17163676. https://doi.org/10.1021/cb600131q

[6] "Zidovudine". The American Society of Health-System Pharmacists.Archived from the original on December 21, 2016.Retrieved November 28, 2016.]

[7] J.Fischer, Ganellin, C. Robin, 2006, Analogue-based Drug Discovery. John Wiley \& Sons.p. 505.

[8] R.Naresh, A.Tripathi, D.Sharma, 2009, Modelling and analysis of the spread of AIDS epidemic with immigrationof HIV infectives, Mathematical and Computer Modelling, 49, 880-892 https://doi.org/10.1016/j.mcm.2008.09.013

[9] F.Bozkurt and F.Peker, 2014, Mathematical modelling of HIV epidemic and stability analysis, Advances in Difference Equations, 95, 1-17. https://doi.org/10.1186/1687-1847-2014-95

[10] M. Robert, 1973,Stability and Complexity in Model Ecosystems, Princeton University Press, New Jersey.

P. Pongsumpun received her bachelor of science in mathematics (second class honors)and the doctor of philosophy in mathematics (international programme) from MahidolUniversity, Thailand. From 2004 to 2012, she was an as assistant professor ofmathematics. From 2012 till date, she is an associate professor of mathematics, thesis Ph.D. and M.Sc. advisors in King Mongkut's Institute of Technology Ladkrabang, Thailand.Her research interests are mathematical modelling in medical science, differential equations and numerical analysis. 